\title{
Phytochemical Investigation of Gynandriris Sisirinchium (Kuwait Medicinal Plants)
}

\author{
HADI A. AL-NAJJAR, Ph.D. \\ The Department of Pharmacy, College of Health Sciences, Public Authority for Applied Education and Training (PAAET), \\ Kuwait
}

\begin{abstract}
Background: Gynandriris sisyrinchium is a traditionally used medicinal plant, yet there is no enough information about its phytochemical profile. In this endeavour.

Aim of Study: We aimed to carry out a detailed phytochemical screening of the active constituents in the bulbs, stems, leaves and flowers of Gynandriris sisyrinchium growing wild in Kuwait.

Material and Methods: Phytochemical screening were done for plant after collection from Kabd Area in Kuwait during March 2005.

Results: The present study results reported moderate presence of cardiac glycosides, carbohydrates and saponins in the bulbs, while Flavonoides are more in the aerial parts. Triterpenes and sterols are present in slight quantities. Also it's clear that the plant is devoid of Alkaloids and Anthraquinones.

Conclusion: The results of the current paper could serve as a starting point for further future investigation of the contents of the Gynandriris syrinchium plant.
\end{abstract}

Key Words: Gynandriris sysirinchium - Iridaceae - Flavonoids - Cardiac glycosides.

\section{Introduction}

PEOPLE usually use plants to help them in many tasks such as shelter, clothing, food, flavours and fragrances and most importantly, medicines [1].

Nowadays, knowledge and information about the ancient botanical medicinal plants practices with their application of modern phytochemical techniques have been proved to be considered excellent powerful tools for the purification and structural elucidation of the different various phytocompounds providing a highlighted insights into their way of action on the human body [2]

In fact, $11 \%$ of the 252 drugs which are reported as basic and essential by the World Health Organ-

Correspondence to: Dr. Hadi A. Al-Najjar, The Department of Pharmacy, College of Health Sciences, Public Authority for Applied Education and Training (PAAET), Kuwait isation (WHO), are exclusively of plant origin and not a little number of synthetic drugs are obtained from natural sources [3].

The Iridaceae is considered a large and interesting plant family with diverse floral structures. Most representatives of that family can be usefully used as ornamental plants because of their beautiful flowers [4].

That family contains about 1750 species in 82 genera [5]. Iridaceae plants are found with wide spread worldwide including different tropical and temperate regions [6].

Plants belonging to that family can be used in traditional medicine for the purpose of different diseases treatment such as cold, flu, malaria, toothache, bruises and also used for burns [7] .

Infusions of C. majalis in small doses can be used for strengthening heart muscles and also as a diuretic $[8,9]$.

In Jordan, the Iridaceae family is including four genera with the names of Crocus L., Gladuolus L., Gynandriris (L.) Parl., and Iris L. In Jordan, G. sisyrinchium is the only species belonging to the Gynandriris genus that grows wild there [10]. In Spain, the plant corm is edible with great caution [11].

Gynandriris sisyrinchium (syn: Iris sisyrinchium and Moraea sisyrinchium) is a perennial herb with a corm, $15-30 \mathrm{~cm}$ in diameter and $10-30 \mathrm{~cm}$ in height, containing pale or dark bluish, violet or purple flower with usually a solitary leaf, (sometimes two) often lying-coiled on the ground. It is native to the southern parts of Europe (Spain, Portugal, Italy, Balearic Islands, Malta, and Greece) and northern of Africa (Egypt and Libya). It is also widespread in south-west Asia especially Pakistan 
and Himalaya. This species mostly prefers clayey loamy textured soil and is commonly found in poor or dry sandy and rocky places in garigue, rocky valleys, rocky steppe, paths, and other open grounds [12].

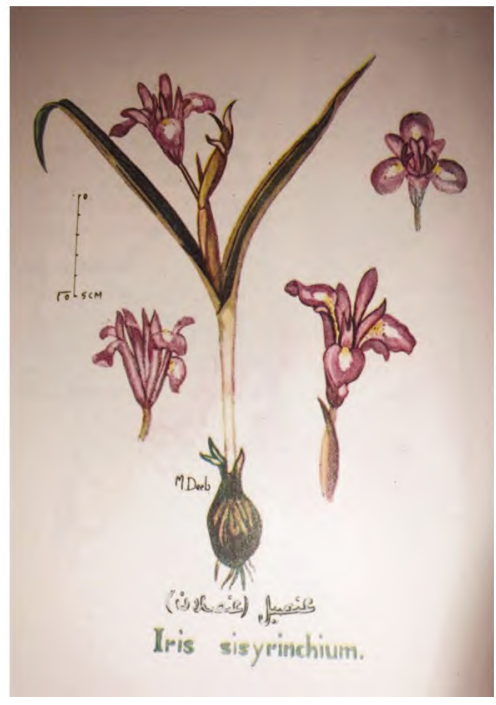

Fig. (1): Iris sisyrinchium.

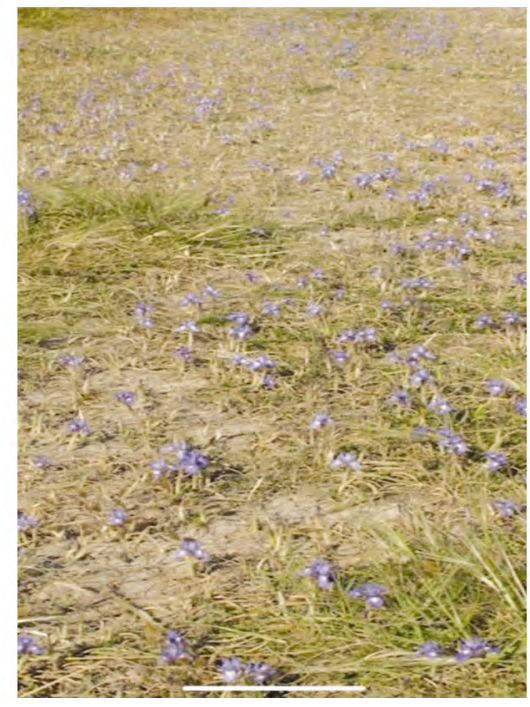

Fig. (2): Nature picture.
Also known as Iris Syrinchium, One of the most beautiful wild flowers that grows in Kuwait During the short spring season in the shallow concave sandy grounds where rain water collects in pounds for a short while. Figs. $(1,2,3)$.
With a violet and white flower and long soared like green leaves with a fibrous fleshy brown bulb that remains hidden 10 centimeters deep below the ground tell the next season $[\mathbf{1 3 , 1 4 , 1 5 ]}$. Flowers and bulbs resemble those found in the liliaceaes like lily of the valley Convallaria majalis where more than 20 cardioactive glycosides like convalltoxin, convallatoxol and convallosid were discovered [16].

The ethnomedicinal uses of G. sisyrinchium have been reported in Pakistan 17 and Egypt [18] It is reported that decoction of its corms is used two times per day as a diuretic in Khyber Pakhtunkhwa, north-west of Pakistan [19]

Although, many plants belonging to the Iris genus have been investigated for their chemical constituents, the phytochemical analysis of the plants belonging to the Gynandriris genus are however rarely reported in the previous literature.

To the best of our knowledge, no previous research studies (at least in Kuwait) were concerned with phytochemical screening of G. sisyrinchium Therefore, The objective of this study is to design the first attempt to explore the in-depth phytochemical analysis of G. sisyrinchium.

\section{Patients and Methods}

\section{Plant material and extracts preparation:}

Gagea sisyrinchium was collected during the flowering period. Fresh whole flowering plants of
G. sisyrinchium were collected from kabd Area of Kuwait during March 2005. Samples were naturally dried in the shade and sent for experimental analysis.

\section{Phytochemical screening:}

Phytochemical screening tests were performed on the different parts of the plant according to standard procedures [14]. The results are given in Table (1).

Table (1): Phytochemical screening tests.

\begin{tabular}{|c|c|c|c|}
\hline Tests for & Bulb & Leaf & Flower \\
\hline $\begin{array}{l}\text { Sterols \& Triterpenes: } \\
\text { Libermanns Test } \\
\text { Salkwiski Test }\end{array}$ & $\begin{array}{l}+\mathrm{ve} \\
+\mathrm{ve}\end{array}$ & $\begin{array}{l}+\mathrm{ve} \\
+\mathrm{ve}\end{array}$ & $\begin{array}{l}+\mathrm{ve} \\
+\mathrm{ve}\end{array}$ \\
\hline $\begin{array}{l}\text { Alkaloids \&/or Nitrogen } \\
\text { Dragendorffs reagent } \\
\text { Mayers reagent } \\
\text { Wagners reagent }\end{array}$ & $\begin{array}{l}-\mathrm{ve} \\
-\mathrm{ve} \\
-\mathrm{ve}\end{array}$ & $\begin{array}{l}\text {-ve } \\
-\mathrm{ve} \\
-\mathrm{ve}\end{array}$ & $\begin{array}{l}-\mathrm{ve} \\
-\mathrm{ve} \\
-\mathrm{ve}\end{array}$ \\
\hline $\begin{array}{l}\text { Cardiac Glycosides: } \\
\text { Keller Kiliani test } \\
\text { Baljet Reaction }\end{array}$ & $\begin{array}{l}++\mathrm{ve} \\
++\mathrm{ve}\end{array}$ & $\begin{array}{l}++\mathrm{ve} \\
++\mathrm{ve}\end{array}$ & $\begin{array}{l}-\mathrm{ve} \\
-\mathrm{ve}\end{array}$ \\
\hline $\begin{array}{l}\text { Flavonoids: } \\
\text { NaOH test } \\
\text { NH4OH Test } \\
\text { AlCl3/UV Test }\end{array}$ & $\begin{array}{l}\text { +ve } \\
+\mathrm{ve} \\
+\mathrm{ve}\end{array}$ & $\begin{array}{l}\text { ++ve } \\
++\mathrm{ve} \\
++\mathrm{ve}\end{array}$ & $\begin{array}{l}\text { ++ve } \\
++\mathrm{ve} \\
++\mathrm{ve}\end{array}$ \\
\hline $\begin{array}{l}\text { Anthraquinones: } \\
\text { Borntragers Test }\end{array}$ & $-\mathrm{ve}$ & $-v e$ & $-v e$ \\
\hline $\begin{array}{l}\text { Tannins: } \\
\text { (FeCl3) Test }\end{array}$ & $-\mathrm{ve}$ & $++\mathrm{ve}$ & $+\mathrm{ve}$ \\
\hline $\begin{array}{l}\text { Saponnins: } \\
\text { Froth Test }\end{array}$ & $++\mathrm{ve}$ & $-v e$ & $-v e$ \\
\hline $\begin{array}{l}\text { Carbohydrates: } \\
\text { Molish Test }\end{array}$ & $++\mathrm{ve}$ & $++\mathrm{ve}$ & $++\mathrm{ve}$ \\
\hline
\end{tabular}




\section{Results and Discussion}

From the table one can notice the Moderate presence of cardiac glycosides, carbohydrates and saponins in the bulbs, while Flavonoides are more in the aerial parts. Triterpenes and sterols are present in slight quantities.

Also it's clear that the plant is devoid of Alkaloids and Anthraquinones.

Gynandriris sisyrinchium (syn: Iris sisyrinchium) is native to the Mediterranean area and flowers during the time extending from the middle to the end of the spring season [7].

Although, as reported by that the non-volatile chemical constituents of G. sisyrinchium have never been investigated before their study. Recently, the chemical constituents of the essential oils get from both the leaves and bulbs of G. sisyrinchium are investigated and reported to have powerful antimicrobial properties [20].

Essential oils produced from Gynandriris sisyrinchium plants have been shown to be used traditionally in many countries for the purpose of respiratory tract infections and colds management

The extract of G. sisyrinchium was investigated to report its antifungal property and to examine its applicaple use as a preservative for wood [4] .

These natural products are reported to have an antimicrobial as well as anti-inflammatory effect

In Kuwait, this species is seldom grazed by livestock [22]. Recently, studies have proved its pharmacological validation reporting antibacterial [20] and antifungal activities [23].

Furthermore, the isolation and characterization of isoflavones from $\mathrm{G}$. sisyrinchium reported significant antioxidant and cytotoxic activity against human promyelocytic leukemia cells HL-60 [4] .

Previous phytochemical screening studies in Gynandriris belonging to the Iridaceae family revealed the presence of various secondary metabolites including flavonoids, biflavonoids, quinones and also xanthones [20].

A review by Komiasarenko and Stupakova revealed Cardiotonics, flavonoids and steroids isolated and synthesized from the genus convallaria [24].

Tittel, G. used photdiode-array-detection (DAD) in HPLC for the detection of biological values of cardiac glycosides in convallaria herb and the results were well correlated with the guinea pig phytochemical assays [25].

Isoflavonoid glycosids on the other hand were isolated from Iris germanica (germanaism A, Germanaism B, irilion and iridin) by Atturahman et al. [26] who in a different study isolated and assayed the anti-inflammatory activities of more isoflavonoids from Iris germanica a member of the family Iridaceae [27].

Iristictorone $\mathrm{K}$ a monocyclic triterpene was isolated and its structure elucidated using HMQC, HMBC, DEPT, COSY, AND NOESY combined experiments from the rhizomes of Iris germanica in Turkey by Orhan et al. [28] .

In the present report, a preliminary phytochemical investigation is carried out on the different parts of Gynandriris sisirinchium with the hope of proving the presence of active constituents. A voucher specimen was deposited at Kuwait University Herbanium.

\section{Conclusion:}

In this preliminary report G.syrinchium, a wild flower that grows in Kuwait during a very short rainy season has proven to contain an appreciable amount of cardiac glycosides, flavonoids and to a lesser extent triterpenes by experiment that correlates with the literature findings especially flavonoids and glycosides mentioned above in the literature survey.

This plant is considered to be one of the rare species in Kuwait and it's worth looking into its constituents for further investigations.

\section{Conflict of interest:}

The authors declare that there is no conflict of interest regarding the publication of this paper.

\section{References}

1- GURIB-FAKIM A.: Medicinal plants: Traditions of yesterday and drugs of tomorrow Mol. Asp. Med., 27: 1-93. 2006.

2- KHAN Z.R., MONI F., SHARMIN S., AL-MANSUR M.A., GAFUR A., RAHMAN O., et al.: Isolation of bulk amount of piperine as active pharmaceutical ingredient (API) from black pepper and white pepper (Piper nigrum L.) Pharmacol. Pharm., 8, 253, 2017.

3- BHAT Z.A.: Traditional medicines in drug discovery $\mathrm{J}$. Pharm. Res., 5: 2457-2459. 2012.

4- AL-QUDAH M., SALEH A., AL-JABER H., TASHTOUSH H., LAHHAM J., ABU ZARGA M., et al.: New isoflavones from Gynandriris sisyrinchium and their 
antioxidant and cytotoxic activities. Fitoterapia, 107: 15-21, 2015.

5- DEVOTO M. and MEDAN D.: Expected mating system, floral diversity and flower visitors of five species of Iridaceae of the Argentine pampas, Acta Botánica Venezuelica, 31: 425-434, 2008.

6- AL-JABER H.I.: Variation in essential oil composition of Iris nigricans Dinsm. (Iridaceae) endemic to Jordan at different flowering stages, Arab. J. Chem., 2013.

7- LIN J., PUCKREE T. and MVELASE T.P.: Anti-diarrhoeal evaluation of some medicinal plants used by Zulu traditional healers, J. Ethnopharmacol., 79: 53-56, 2002.

8- NAJM Y.A.: A Dictionary of Medicinal Plants. Library Du Liban, Beirut, 1999.

9- ZAKARY A.: Medicinal Plants. Tehran University, Iran, 1989.

10- AL-EISAWI D.M.: List of Jordan vascular plants. In: Mitt. Bot. Munchen, 18: 79-182, 1982.

11- OZEN E., YENIOCAK M., GOKTAS O., ALMA M.H. and YILMAZ F.: Antimicrobial and antifungal properties of Madder root (Rubia tinctorum) colorant used as an environmentally friendly wood preservative, Bioresources, 9: 1998-2009, 2014.

12- ÖZDEMIR C., ALÇITEPE E. and SEPET H.: Morphological, anatomical and ecological studies of Gynandriris sisyrinchium (L.) Parl in Turkey Thaiszia J. Bot., 21: 19, 2011.

13- DEEB M. and ALSALEM K.: Wild plants of Kuwait, AlJallal publications, Kuwait, 1974.

14- AL-RAWI A.: Kuwaits wild plants Reference. KFAS, Kuwait, 1985.

15- SHEIHA M.Y.: Plant developments in Kuwait. KFAS, Kuwait, 1984.

16- TYLER V.E., BRADY L.R. and ROBERTS J.E.: Pharmacognosy, 9th Edn. Lea \& Febiger, Philadelphia, 1988.
17- SHER H., ELYEMENI M., SHER H. and HUSSAIN K.: Ethnobotanical and economic observations of some plant resources from the Northern Parts of Pakistan Ethnobot. Res. Appl., 9: 027-041, 2011.

18- BIDAK L.M., KAMAL S.A., HALMY M.W.A. and HENEIDY S.Z.: Goods and services provided by native plants in desert ecosystems: Examples from the northwestern coastal desert of Egypt Glob. Ecol. Conserv., 3: 433-447, 2015.

19- SHER H., ALDOSARI A., ALI A. and De BOER H.J. Indigenous knowledge of folk medicines among tribal minorities in Khyber Pakhtunkhwa, northwestern Pakistan J. Ethnopharmacol., 166: 157-167, 2015.

20- AL-QUDAH M.A., MUHAIDAT R., TRAWENH I.N., AL JABER H.I. and ZARGA M.H.A.: Volatile constituents of leaves and bulbs of Gynandriris sisyrinchium and their antimicrobial activities Jordan J. Chem., 7: 287-295, 2012.

21- SHUBINA L.P., SIURIN S. A. and SAVCHENKO V.M.: Vrachebnoe Delo (Kiev) Part 5: 66-7. J.P. 1990.

22- MANDAVILLE J.P.: Bedouin Ethnobotany: Plant Concepts and Uses in a Desert Pastoral World University of Arizona Press, 2011.

23- GOKTAS O., OZEN E., BAYSAL E., MAMMADOV R. and ALMA M.H.A.: research on the usage of extracts from two poisonous plants (Muscari neglectum Guss. and Gynandriris sisyrinchium (L.) Parl.) as a wood preservative Wood Res. (Bratislava), 55: 53-62, 2010.

24- KOMIASSARENKO N.F. and STUPAKOVA E.P.: Rastet. Resur., 25 (3): 253-68, (Russ), 1989.

25- TITTEL D.: Card. Glycosides., 1785-1985: 315-21, 1986.

26- ATTA-UR-RAHMAN, SHAMA N. and ERFAN B.: Chemical \& Pharmaceutical bulletin, 50 (8): 1100-1102, 2002.

27- ATTA-UR-RAHMAN, SHAMA N., ERFAN B., SAIMA J. and ORHAN I.: Journal of Ethnopharmacology, 86 (23): 177-180, 2003.

28- ORHAN I., BEILGE S., HASHIMOTO T. and ASAKAWA Y.: Fitoterapia., 73 (4): 316-319, 2002. 


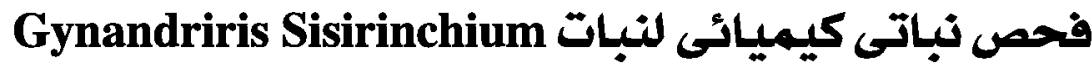 (نباتات الكويت الطبية (نبية)}

نبات Gynandriris Sisirinchium هو نبات طبى يستخدم بشكل تقليدى، و لكن لا توجد معلومات كافية حل ملفه الكيميائى النباتى. الهدف من الدراسة: تم تصميم هذه الدراسة لإجراء مسع كيميائى للمكونات الفعالة في البصيلات والسيقان والأفداق والزهيد لنبات Gynandriris Sisirinchium والتى تنمو بريا في الكويت.

خطة البحث: كان هدفنا إجراء مسيح كيميائى للمكونات الفعالة في البصيلات والسيقان والأقداق و الزهود لنبات Gynandriris Sisirinchium

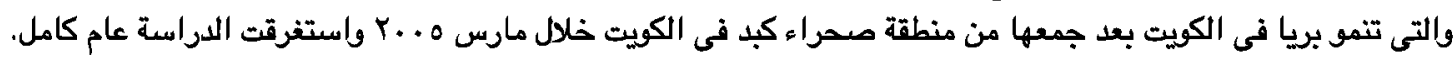
نتائج البحث: أثارت نتائج الدراسة الحالية إلى وجود معتدل للجليكيسيدات والكربوهيدرات في البصيلات، في حين أن الفلافونويد أكثر

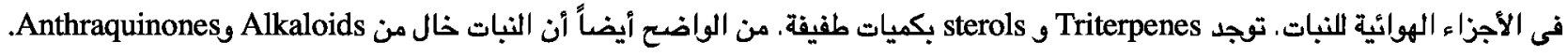
الخلاصدة: وأخيراً يمكن أن تكىن نتائج هذه الدراسة بمثابة نقطة بداية لانطلاق المزيد من الفحص الكيميائى فى المستقبل فى محتويات 